\title{
A Stakeholder Perspective on Family Firm Performance
}

\author{
Thomas M. Zellweger, Robert S. Nason
}

\begin{abstract}
Through the lens of stakeholder theory, this article deepens our understanding of financial and nonfinancial performance outcomes in family firms across multiple stakeholder categories, including the family level of analysis. Based on this foundation, we develop a typology of performance relationships between performance outcomes: overlapping, causal, synergistic, and substitutional. We argue that these relationships, when used between constructive (positive) performance outcomes, are able to increase stakeholder satisfaction, which in turn increases organizational effectiveness. Through this analysis, we extend the common one-dimensional and cause-effect understanding of performance in family firms and move toward a comprehensive stakeholder performance perspective, which provides insights for increasing organizational effectiveness of family firms.
\end{abstract}

\section{Introduction}

Recent academic literature has suggested financial outperformance of family firms compared to nonfamily firms (Anderson, Mansi, \& Reeb, 2003; Villalonga \& Amit, 2006; Zellweger, Fueglistaller, \& Meister, 2007). Although there is a debate challenging the authenticity of this claim, there have nevertheless emerged those who have sought to identify the source of family firm performance. Habbershon, Williams, and MacMillan (2003) use the resource-based view to tie the unique bundle of capabilities and resources-the family firm's "familiness"-to competitive advantage. This family effect has been evaluated for its influence on trust-based organizational culture (Corbetta \& Salvato, 2004), human resource management (Sraer \& Thesmar, 2006), loyalty of employees (Ward, 1988), decision making (Poza, Alfred, \& Maheshwari, 1997), agency costs (Schulze, Lubatkin, \& Dino, 2003), and continuity and the longer-term horizon (Zellweger, 2007).

In this attempt to explain performance, however, research in the family business literature has historically focused on a single variable of performance measurement (Westhead \& Cowling, 1997), for instance, employment, profits, value-added, sales revenue, assets, or return on assets. In a comprehensive literature review, Jaskiewicz (2006) finds that for quoted firms the most used performance measure is stock market performance or Tobin's $Q$, the market value of total asset divided by its replacement of the asset, whereas for unquoted firms, return on equity, return on assets, or gross profit margin are among the most used measures of performance. However, it has been suggested that profit maximization may have been inaccurately assumed to be the primary or even sole objective of a family business and that family firms often display a strong preference toward noneconomic outcomes (see Figure 1) (Chrisman, Chua, \& Litz, 2004; Craig \& Moores, 2005; Dunn, 1995; Gomez-Mejia, Takacs Haynes, Nunez-Nickel, Jacobson, \& Moyano-Fuentes, 2007; Lee \& Rogoff, 1996). In addition, empirical evidence beyond the family firm arena suggests that traditional financial measures based on firm profitability are inadequate for evaluating the strategic performance of any firm (Chakravarthy, 1986). 
The existence of nonfinancial outcomes is widely acknowledged in the entrepreneurship and family business literature, but researchers have traditionally assumed that different performance outcomes need to be substitutional in the sense that one performance outcome is only achievable at the expense of the other (e.g., control vs. profitability) (McMahon \& Stanger, 1995). However, there has been preliminary evidence in more mainstream management literature showing that performance outcomes can have other, for example, synergistic effects (Chrisman \& Carroll, 1984). Despite some discussion of performance relationships, little has been done to analyze their effect on broader stakeholder satisfaction and, thus, organizational effectiveness (Connolly, Conlon, \& Deutsch, 1980; Miles, 1980). Given that family firms often need to simultaneously satisfy multiple stakeholders with financial and nonfinancial performance demands, there is a need to comprehensively explore how different performance dimensions are interrelated and how they allow efficient satisfaction of multiple stakeholders. In light of these considerations, we strive to answer, first, what relationships exist between performance outcomes and, second, how these relationships impact organizational effectiveness through the satisfaction of multiple stakeholders.

By providing answers to these two research questions, the contribution of our article is threefold. First, we extend family business literature by applying stakeholder theory (Freeman, 1984) to the family firm and performance context as sug- gested by family business scholars (Sharma, 2004). Second, with the proposed performance relationships we build on Dess, Ireland, Zahra, Floyd, and Janney (2003), who propose that a stakeholder analysis may include other (e.g., mutually beneficial) performance relationships. Third, we discuss how the use of the different performance relationships may help or hinder family firms in increasing organizational effectiveness, considering financial and nonfinancial performance demands by stakeholders. Thereby, we add to the literature on the relevance of nonfinancial performance outcomes in family businesses (e.g., Astrachan \& Jaskiewicz,forthcoming; Gomez-Mejia et al.,2007).

Our article is structured as follows. First, we explore the relevance of stakeholder theory in the family firm context. Second, we provide a classification of stakeholders based on levels of analysis and provide examples of performance outcomes according to stakeholders. Third, we delineate relationships between different performance dimensions. Fourth, we outline how the proposed performance relationships affect organizational effectiveness. We conclude with a general discussion of our findings, limitations of our study, and suggestions for future research.

\section{The Relevance of Stakeholder Theory in the Context of Family Firm Performance}

There has been criticism in the field of family business research that there is an "implicit

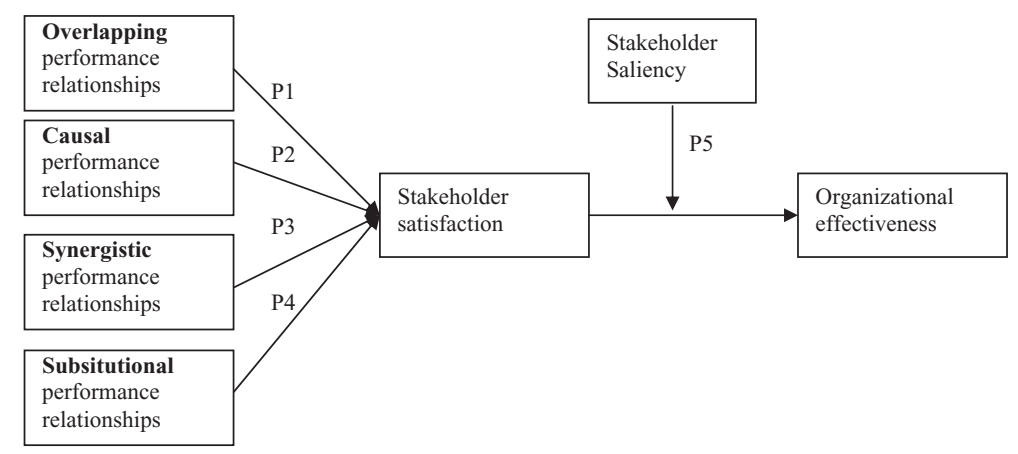

Figure 1 Research Model. 
assumption that economic performance is their [family businesses] sole goal" (Chrisman et al., 2004, p. 338). This bias toward analyzing only the financial performance of family firms is evident in the family versus nonfamily performance literature. As stated previously, the most cited performance study in the family business arena (Anderson \& Reeb, 2003) uses Tobin's $Q$ and return on asset as performance measures.

Yet, whereas family firms' emphasis on outcomes related to the family is rather well understood, their emphasis on nonfinancial performance outcomes not related to the family is not as well understood. In the same way that there has been an attempt to explain financial performance of family firms, there needs to be a theoretical explanation for the nonfinancial outcomes of family firms. In this attempt to shed some light on the nonfinancial performance dimensions, Sharma (2004) and Litz (1997) propose that stakeholder theory might be helpful. To further substantiate the relevance of applying stakeholder theory to the family firm context, as suggested by the above authors, we propose three arguments.

First, in contrast to nonfamily enterprises, family firms have de facto an additional stakeholder group, the family. We follow the definition of a family business proposed by Chua, Chrisman, and Sharma, where "the family business is a business governed and/or managed with the intention to shape and pursue the vision of the business held by a dominant coalition controlled by members of the same family or a small number of families in a manner that is potentially sustainable across generations of the family or families" (1999, p. 25). With this understanding, family firms' uniqueness arises from the role of family as a key stakeholder. As such, the family stakeholder group has unique goals, many of which can be considered noneconomic, such as harmony, jobs for family members, and family control.

Second, given that individuals in family firms often play multiple stakeholder roles (e.g., employee, owner, manager, family member), we may expect that family firms have a higher incentive to ensure the particular satisfaction of the related individual stakeholders and stakeholder groups. Based on social identity theory, Dyer and Whetten (2006) show that family entrepreneurs often view their firms as an extension of the self and their families, which makes them more likely to be socially responsible and, hence, satisfy societal stakeholders. These attempts are reinforced by the fact that family members cannot switch groups (the family) or easily change organizations, thus creating an even stronger incentive for individuals in the family firm to satisfy multiple stakeholders.

Third, family enterprises have been reported to display strong community relations (Tagiuri \& Davis, 1996) and as being embedded in the societal context of their firms. Sirmon and Hitt (2003) report that family firms display richer social capital due to their transgenerational outlook. Sirmon and Hitt (2003) find that (trans)generational outlook and patient capital allow family firms to devote the proper time to cultivating the necessary relationships with societal stakeholders, allowing these firms to establish more effective relations with support organizations (e.g., banks), while maintaining legitimacy with other important constituencies and societal stakeholders (Lounsbury \& Glynn, 2001).

In sum, we find good reasons why family firms have a particular inclination to satisfy multiple stakeholders. Beyond Sharma's (2001, 2003, 2004) work that suggests that stakeholder theory offers the opportunity to classify family firms, we consider that it also provides a useful framework to evaluate the breadth and the relationships between different performance outcomes.

\section{Stakeholder Categories and Corresponding Performance Outcomes}

Performance outcomes in family firms have been broadly categorized as financial and nonfinancial or family outcomes and business outcomes (Dunn, 1995; Olson et al., 2003; Sorenson, 1999). However, there has not been a comprehensive view of performance outcomes for family firms taking all stakeholders into account. As Chua, Chrisman, and Steier (2003, p. 333) state, "a 
paradigm for family firms would have to expand its goal set to include benefits unrelated to financial and competitive performance." In Freeman's fundamental work on stakeholder theory, he defines a stakeholder as "any group or individual who can affect, or is affected by, the achievement of a corporation's purpose" (1984, p. 6). ${ }^{1}$ Following the observation that stakeholders have different demands, firms will produce different performance outcomes to meet those stakeholderspecific demands. In line with Davidsson and Wiklund (2001) and Scott and Rosa (1996), we acknowledge that entrepreneurship occurs and affects different levels of analysis simultaneously. Considering these calls for multiple levels of analysis and Lansberg's (1988) consideration on family, business, and ownership overlaps, we consider four distinct stakeholder levels of analysis.

First, on the individual owner and manager level of analysis, Douglas and Shepherd (2000, 2002) argue that owner-managers not only derive benefit from the income streams related to the entrepreneurial activity, but that entrepreneurs also consider "working conditions," including benefits like decision-making autonomy (Douglas \& Shepherd, 2002; Gimeno, Folta, Cooper, \& Woo, 1997); power, prestige, and personal reputation (Baumol, 1990), job challenge and sense of belonging (Naughton, 1987); the legacy value from continuing a family tradition, emotional bonds between family members; and nostalgia (Sharma \& Manikutty, 2005; Ward, 1997).

Second, the organization as a stakeholder level of analysis is the most prevalent in classic performance and organizational effectiveness literature. The fact that the organization is a critical stakeholder is self-evident: Without adequate organizational performance, in the long run the organization itself would cease to exist. Penrose (1952, p. 810) states this theoretical view as that

\footnotetext{
${ }^{1}$ Freeman provides the following list of stakeholders: owners, employees, unions, customers, competitors, consumer advocates, suppliers, media, environmentalists, governments, local community organizations, political groups, financial community, trade associations, activist groups, and special interest groups (1984, p. 25).
}

"positive profits can be treated as the criterion of natural selection-the firms that make profits are selected or 'adopted' by the environment, others are rejected and disappear." Examples of performance outcomes that satisfy the demands of the organizational-level stakeholders include salary and job security for employees; growth in sales, growth in employees, profitability, and company reputation; timely payment to suppliers; and innovative products and services, new ventures, and quality products for customers.

Third, the relevance of society as a stakeholder unit of analysis is reflected in the blossoming literature surrounding corporate social responsibility (e.g., McGuire, Sundgren, \& Schneeweis, 1988) and social entrepreneurship (e.g., Austin, Stevenson, \& Wei-Skillern, 2006). Generally speaking, societal stakeholders can be considered as any individual or group external to the organization that is affected by the purpose of the organization. Within our classification based on the stakeholder list by Freeman (1984), examples include the local community, interest groups, political groups, and governments. Constructive performance outcomes to satisfy societal stakeholder demands include philanthropy, social or environmental initiatives, funding and support of nonprofit organizations, and job creation or sustainment in areas with high unemployment rates.

Fourth, given the central role of the family in controlling the strategic direction (Chua, Chrisman, \& Sharma, 1999) of the firm and the unique family goals in family firms, we need to add to the family as an additional stakeholder category to above list. Several models have tried to capture the overlap between family and business and the resulting role and goal conflicts (e.g., Habbershon et al., 2003; Schulze et al., 2003; Tagiuri \& Davis, 1996). Ward (1997) and Vos and Forlong (1996) stress that performance in family firms is a function of the idiosyncratic goal set of the family. This idiosyncratic and self-defined goal set is often reflected by a high striving for autonomy in terms of financing (Ward, 1997), business culture (Corbetta \& Salvato, 2004), and the selection of long-term investment opportunities (Zellweger, 2007). Other performance outcomes that satisfy 
the demands of the family-level stakeholder include not only financial dimensions, such as family wealth, but also nonfinancial measures, such as control, continuity, family pride, harmony, trustful relations, family reputation, sense of belonging, and cohesion (Ward, 1997). With their impact on goal setting and deriving outcomes from the business, ownership families clearly affect, and are affected by, the achievement of a corporation's purpose (Freeman, 1984) in a unique stakeholder category capacity.

Stakeholder units of analysis are useful to distinguish individual stakeholders and corresponding performance outcomes; however, much of the idiosyncrasy of the family business system (Habbershon et al., 2003) is reflected in the relationships between performance outcomes. Since family firms wish to satisfy multiple stakeholders, it is useful to evaluate the ways various performance outcomes function to satisfy multiple stakeholders and cut across levels of analysis.

\section{Relationships Between Performance Outcomes}

Thinking beyond the more established understanding of substitutional effects between performance outcomes (e.g., lifestyle vs. return) and some preliminary evidence in the literature on synergistic effects between performance outcomes (Chrisman \& Carroll, 1984), we propose a typology of performance relationships. ${ }^{2}$ Viewing this as an effort toward theory development, we propose a typology (Doty \& Glick, 1994) that allows for a holistic approach to performance research and nonlinear relationships among constructs. By holistic we mean that we are attempting to explain the "complex multidimensional pattern of organizational attributes" (Doty \& Glick, 1994, p. 244)—in this case, relationships

\footnotetext{
${ }^{2}$ We frame the following sections using examples of the performance relationships existing between constructive (positive) performance outcomes, but the relationships also exist between destructive (negative) performance outcomes, in which case, we argue, they will have a negative effect on organizational effectiveness.
}

between performance outcomes. By nonlinear relationships between constructs we suggest that performance outcomes exist in more complex patterns than simple cause and effect relationships. The performance typology consists of overlapping, causal, synergistic, and substitutional relationships, which represent differing ways to create stakeholder satisfaction and enhance organizational effectiveness.

\section{Overlapping Relation Between Performance Outcomes}

By overlapping relation between different performance outcomes we mean that one performance outcome can satisfy multiple stakeholders. This can occur with both financial and nonfinancial outcomes.

As an example of the overlapping relationship with a financial outcome, we consider the capacity of shareholder value to satisfy multiple stakeholders in a family firm with several family and nonfamily owners. Increased shareholder value will satisfy (in part) demands of the individual owner since it increases his or her own financial wealth. Furthermore, the family will experience satisfaction since shareholder value increases family wealth and provides the possibility of earning dividends and receiving perquisites. Additionally, external owners, as organizational stakeholders, are satisfied since their ownership stake increases in value.

In a similar way, but with a nonfinancial outcome, positive corporate reputation can be experienced by multiple stakeholder categories. Due to the strong identity overlap between individual, family, and business (Dyer \& Whetten, 2006), the business reputation will be felt as an individual and family reputation (and vice versa), creating value for the individual, the family, and the organization at the same time, for the same performance outcome. Furthermore, it can be argued that reputation will satisfy societal stakeholders, for instance, the local community since they will derive value from a popular and respected business in their neighborhood. 


\section{Causal Relations Between Performance Outcomes}

By causal relations between performance outcomes we mean that one performance outcome causes other performance outcomes, which in turn satisfy different stakeholders.

For example, philanthropy, such as donating to cancer research, will satisfy societal stakeholders such as the research organization, cancer patients who are helped, and the community at large, which recognizes this positive contribution. Besides societal outcomes, philanthropy can create tax advantages for the organization, which can be positively valued by owners. As a further example, consider family harmony as a familyspecific performance outcome. Creating family harmony and the resulting trust-based relationships among managers can strengthen joint efforts to create innovative products at the organizational level (Corbetta \& Salvato, 2004). At the same time, harmonious family relations between family owners and managers may reduce agency costs between owners and managers, which spares the firm the installment of expensive control mechanisms, thereby increasing family wealth.

\section{Synergistic Relations Between Performance Outcomes}

By synergistic relations between performance outcomes we mean that two different performance outcomes can mutually affect each other in the same direction (positively or negatively).

Synergistic effects of performance outcomes are commonly recognized between financial outcomes of firm activity. For example, the performance outcomes of sales (organizational stakeholder outcome) and return on assets (family stakeholder outcome) can have a synergistic effect on each other. As sales increase, and if the cost structure and the assets are held constant, the return on assets will also grow. Due to synergistic effects, even the pursuit of noneconomic goals does not necessarily destroy economic value. As Jensen and Meckling (1994) note, when owner-managers maximize a utility function that includes noneconomic goals, there does not have to be a loss of economic efficiency. In fact, Chrisman and Carroll (1984) have demonstrated that firms that strategically manage the pursuit of social goals can actually enhance their economic performance and produce a systemic, synergistic effect on wealth creation. In the same way that Chrisman and Carroll (1984) demonstrate a synergistic effect between social and organizational outcomes, we suggest that performance outcomes across other stakeholders and performance dimensions can relate synergistically to one another. This is in line with Dess et al.(2003), who propose that a stakeholder analysis need not implicitly involve tradeoffs among the various stakeholders, but that symbiotic relationships can exist.

Synergistic effects can occur for performance outcomes within one stakeholder category or across stakeholder categories, as well as between financial and nonfinancial performance outcomes. For instance, the positive financial performance of a firm (e.g., sales growth) can lead to an increased reputation of the organization (as well as the family and individual manager). The company reputation can be leveraged in the marketplace among suppliers, customers, and capital providers (Sirmon \& Hitt, 2003). The cycle then continues as the synergistic effect between sales growth and reputation leads to greater amounts of both outcomes.

\section{Substitutional Relations Between Performance Outcomes}

By substitutional relations between performance outcomes we mean that two different performance outcomes can be traded one for the other. Tradeoff possibilities include deciding between two positive outcomes, deciding between two negative outcomes, or balancing positive and negative outcomes.

Entrepreneurial activity may, at times, lead to favorable outcomes on one performance dimension and unfavorable outcomes on a different performance dimension. The substitutional effect of performance dimensions is how scholars have 
traditionally handled the relationship between family and business outcomes (McMahon \& Stanger, 1995). Although we have shown that this does not have to be true, due to the synergistic effect, it certainly can be true.

With regard to organizational outcomes, for example, heavy investment in $\mathrm{R} \& \mathrm{D}$ and product innovation may enable a firm to successfully enter new product-market domains and consequently enhance sales growth in the long run. However, the requisite resource commitment may detract from short-run profitability (Lumpkin \& Dess, 1996). Similarly, increasing the leverage of the firm may assure its survival as it enables the business to tackle critical investments; on the dimension of independence, however, one of the predominant goals of family firms (Ward, 1997), this can be considered a loss.

In this context, Gimeno et al. (1997) suggest that organizational survival and performance is not strictly a function of economic performance but that poorly performing ventures sometimes continue because of psychic returns to the individual. Furthermore, Douglas and Shepherd (2000) find that individuals face a utility maximization problem between an entrepreneurial career path with a higher expected salary but a higher risk, versus a lower salary at a lower risk in organizational employment.

Certain tradeoffs, for example, between salary and leisure time, could be framed as "giving up a positive, to get another positive." However, further substitutional trades are conceivable. For instance, trades are possible where individuals "give up a positive, to reduce a negative" (e.g., give up sole decision power to reduce family quarrels). Furthermore, individuals may face the situation where they "accept a negative outcome to reduce another negative," or where they "accept a negative outcome to obtain/increase a positive" outcome related to their entrepreneurial activity. For instance, we consider an owner-manager who accepts family quarrels between family employees to avoid exclusion of a family member from the firm. Correspondingly, a family manager can be willing to accept family quarrels to assure the independence of the firm.

\section{Stakeholder Performance Typology in Action}

To provide an overview on how a system of overlapping, causal, synergistic, and substitutional performance outcomes can function, consider the example of an individual owner-manager who decides how to use the firm's distributable earnings. The individual faces the tradeoff of whether he or she wants to consume a share of the firm's income as perks or whether the individual prefers to spend a share on philanthropic activities. Spending it on philanthropy can cause two further performance outcomes, community development and tax relief. Whereas tax relief is of value to all owners (the individual, the family owners, and the family external organizational owners), community development is of value to society and, more specifically, the special interest group supported. Community development will also create pride and a sense of well being at the family level and also at the personal, individual level. The positive feeling of pride for the family and the individual can in turn induce a further engagement in philanthropy and community development in a synergistic way. Furthermore, community development will also enhance reputation, which is valued by the individual, the business family, and organizational stakeholders, as shown above. These intertwined relations of family firm performance across stakeholder groups are displayed in Figure 2.

\section{Organizational Effectiveness and Performance Relationships}

Organizational effectiveness, in what is known as the ecology model, is defined as "the ability of the organization to satisfy the expectations of its strategic constituents" (Miles, 1980, p. 375). Individuals become involved with an organization (as owners, managers, employees, customers, suppliers, regulators, etc.) for a variety of different reasons, and these reasons will be reflected in a variety of different evaluations. Therefore, it appears arbitrary to label one of these perspectives a priori as the "correct" one, since 


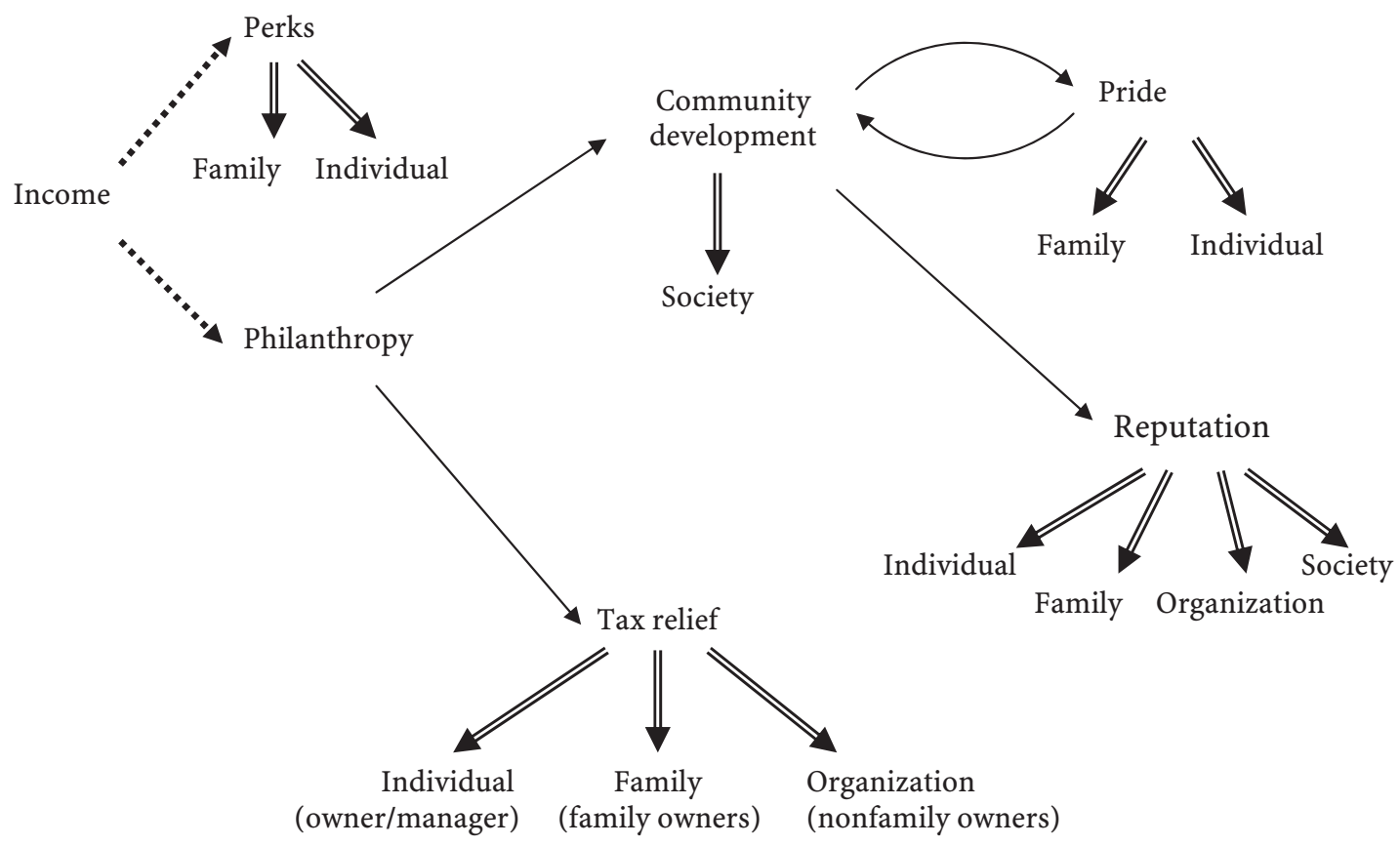

$\Longrightarrow$ Overlapping: One performance dimension satisfies multiple stakeholder categories / stakeholders.

$\longrightarrow$ Causal: One performance dimension causes other performance dimension(s).

$\ldots \rightarrow \quad$ Tradeoff: Two different performance outcomes can be traded one for the other.

Synergistic: Two different performance outcomes can mutually effect each other in the same direction (positively or negatively).

Figure 2 Performance Relationship Typology in Action.

stakeholders may assess organizational effectiveness through differing, incompatible, and changing criteria (Cameron \& Whetten, 1983; Connolly et al., 1980; Lewin \& Minton, 1986).

In the definition of organizational effectiveness outlined above, it is clear that stakeholder satisfaction plays a pivotal role. Given the multitude of performance criteria applied by different stakeholders, it is useful for family firms to assess the ways various performance outcomes function to satisfy multiple stakeholders in order to make effective use of organizational initiatives and outcomes. The proposed performance relationship typology provides insight into how performance outcomes for various stakeholders interact with each other and thus impact organizational effectiveness. For example, overlapping and causal relationships have the capacity to satisfy multiple stakeholders with one performance outcome. Therefore, we suggest that making use of constructive (positive) overlapping and causal performance relationships will increase organizational effectiveness, since the demands of multiple stakeholders can be satisfied with one performance outcome. This leads us to the following propositions.

Proposition 1. The degree to which there are overlapping relationships between constructive 
performance outcomes is positively associated with stakeholder satisfaction, which, in turn, is positively associated with organizational effectiveness.

Proposition 2. The degree to which there are causal relationships between constructive performance outcomes is positively associated with stakeholder satisfaction, which, in turn, is positively associated with organizational effectiveness.

Synergistic relations occur when two different performance outcomes mutually affect each other in the same direction, as discussed above. Thereby, one or multiple stakeholders can benefit from the synergistic effect. This synergistic effect not only allows creating multiple performance outcomes, but simultaneously increases them, thereby positively impacting the satisfaction of involved stakeholders (e.g., sales growth and corporate reputation, number of jobs and family reputation). As a result, synergistic relationships between two constructive performance relationships increase organizational effectiveness. Given the above observations, we introduce the following proposition.

Proposition 3. The degree to which there are synergistic relationships between constructive performance outcomes is positively associated with stakeholder satisfaction, which, in turn, is positively associated with organizational effectiveness.

However, a cumulative effect of performance outcomes is not always possible as there are situations where, given a firm's limited resources, stakeholder demands are mutually exclusive, as shown with substitutional performance relationships. The implicit assumption is that substitutional relations do not increase stakeholder satisfaction and hence organizational effectiveness since an increase in one dimension is conceivable only at the expense of another one. Moores and Barrett (2002) refer to similar tradeoffs as paradoxes within family firms that need to be effectively managed. In a similar vein, we argue that, taking a stakeholder perspective, it is conceivable that substitutional effects can be managed to mitigate con- flicting stakeholder demands, thereby potentially increasing the overall organizational effectiveness.

Therefore, depending on differences in stakeholder saliency, defined as the influence levels of stakeholders (Kochan \& Rubinstein, 2000; Mitchell, Agle, \& Wood, 1997), the shifting of priorities between different performance dimensions may lead, taken together, to an increase in strategic stakeholder satisfaction. For example, at times, family firms may be better off to reduce family wealth in the short run to assure timely payment of a key supplier that delivers critical supplies for a running production process. Hence, even though timely payment of the supplier can be achieved only at expense of family wealth, this substitutional performance relationship can increase organizational effectiveness. This is related to the fact that, taken together, the satisfaction of the supplier, as the more salient stakeholder in this specific situation, could be maintained or increased, thereby more than outweighing the short-run decrease in family satisfaction.

In sum, in contrast to the other performance dimensions where cumulative effects between performance outcomes and stakeholders take place, in the case of substitutional relations, the effectiveness of substitutional relationships will depend on the overall effect as perceived by strategic constituents. More formally stated:

Proposition 4. The degree to which substitutional relationships between performance outcomes positively affect strategic stakeholders is positively associated with organizational effectiveness.

As shown above for substitutional performance relationships, stakeholder saliency plays a central role in determining whether organizational effectiveness can be increased. Stakeholder saliency is also expected to play a pivotal role in the context of the other three performance relationships. Although causal, overlapping, and synergistic relationships will all increase stakeholder satisfaction, as with substitutional relationships, the degree to which this stakeholder satisfaction translates to increased organizational effectiveness depends on the saliency of stakeholders 
satisfied. We expect that the more salient, hence the more influential or strategic, the constituent, the higher the impact on organizational effectiveness. Following Whetten (2007), if the family is central and the business is seen as an arena for family life and hence the family is a key stakeholder, the family's saliency will actually strengthen the positive effect of satisfaction family demands and organizational effectiveness. In the opposite case, that is, a "business first" family firm, organizational stakeholders might be more salient. In turn, the positive effect of organizational stakeholder satisfaction on organizational effectiveness will be supported by the saliency of this type of stakeholders. Stated more formally:

Proposition 5. The relationship between stakeholder satisfaction and organizational effectiveness is moderated by stakeholder saliency, with high levels of stakeholder saliency supporting the stakeholder satisfaction and organizational effectiveness link.

\section{Conclusion and Implications}

Our study followed Sharma's (2004) call to apply stakeholder theory to examine family firm performance. Due to the existence of an additional stakeholder category, the family, and the tight overlap between the individual, the firm, and the family (Dyer \& Whetten, 2006) and the close connection to society (Sirmon \& Hitt, 2003), we argue that family firms exhibit an innate incentive to satisfy the demands of multiple stakeholders. Using Lansberg's (1988) three-circle model and Freeman's (1984) list of stakeholders, we extracted four stakeholder levels of analysis relevant in the family firm context-individual, family, organization, and society-and identified corresponding performance outcome examples for stakeholders in each of these categories.

Through the lens of stakeholder theory, we developed a typology of performance relationships. This typology provides a deeper understanding of the relationships between performance outcomes, given that certain outcomes of business activity do not exist independently of each other, but are related. Thereby, we follow Dess et al. (2003), who propose that a stakeholder analysis need not implicitly involve tradeoffs among the various stakeholders but may include other (e.g., symbiotic) performance relationships (Chrisman \& Carroll, 1984). The typology we propose includes the following types of performance relationships: overlapping, one performance outcome satisfies multiple stakeholders/stakeholder categories; causal, one performance outcome causes other performance outcome(s); synergistic, two different performance outcomes can mutually affect each other in the same direction (positively or negatively); and substitutional, two different performance outcomes can be traded one for the other.

Furthermore, we discuss how the understanding about the proposed performance relationships may help increase the family firm's effectiveness in satisfying strategic stakeholders. We find that making use of overlapping and causal relationships, which have the capacity to satisfy multiple stakeholders with one performance outcome, increases organizational effectiveness of family firms. Similarly, we show that synergistic relationships between two positive performance relationships increase organizational effectiveness since they positively impact the satisfaction of one or multiple stakeholders. We propose that even in the case of substitutional performance relationships, when one performance outcome can be achieved only at the expense of another, organizational effectiveness can be increased, depending on the overall effect of the performance outcomes as perceived by strategic constituents. Finally, our considerations show that stakeholder saliency moderates the positive relationship between stakeholder satisfaction and organizational effectiveness.

\section{Implications for Research}

Our considerations show that when allowing for multiple financial and nonfinancial performance goals across stakeholders, performance management that strives to satisfy these stakeholder demands is a challenging and intriguing area of research. For example, empirically testing synergistic relationships is an interesting avenue for 
future research. The idea that two performance outcomes do not need to be mutually exclusive or traded one for the other, especially in the family business context, but that they can actually have a reinforcing (synergistically positive or negative) effect, warrants further investigation. Moreover, investigating the substitutional effects between performance dimensions is a further avenue to explore. Examining how gains and losses related to entrepreneurial activity are evaluated and mentally accounted (Thaler, 1985) could help in understanding how entrepreneurial initiatives are evaluated and why certain initiatives are undertaken and why others are not.

Another important avenue for future research would be applying systems theory (Schilling, 2000) and Habbershon et al.'s (2003) considerations to performance relationships. The familiness and family systems model by Habbershon et al. (2003) could provide insight into the sources and combinations of idiosyncratic performance outcomes and how a system of performance relationships can be channeled to create a competitive advantage.

What is more, researchers could explore types of family firms, since family firms with differing emphasis on family-related versus business-related aspects (Melin \& Nordqvist, 2007; Whetten, 2007) are expected to differ not only regarding governance structures but also regarding relevant performance dimensions.

In sum, the stakeholder perspective of family firm performance is useful in the ongoing debate as to how success is defined in family firms. If family firms are more likely to satisfy multiple stakeholders, they are likely to measure success by how well they satisfy their whole stakeholder base. Along this line, future research on family firm performance should investigate the question as to whether the satisfaction of multiple stakeholders helps in attaining an ultimate goal of long-term survival of these organizations (Ward, 1997).

\section{Implications for Practitioners}

In contrast to a one-dimensional and cause-effect understanding of performance, family firm practitioners should focus on evaluating performance from a holistic stakeholder perspective and pursue the performance dimensions that create the highest impact across the most relevant stakeholders, thereby leveraging organizational effectiveness.

Practitioners can use the stakeholder performance framework to increase overall organizational effectiveness. To this end, practitioners need to identify the most influential stakeholders. Then, the performance outcomes relevant to the identified stakeholders can be explored. Finally, in order to increase organizational effectiveness, the typology of performance relationships can be used to discuss ways to effectively produce these performance outcomes, thereby generating the highest beneficial impact among the most salient stakeholders.

The stakeholder perspective to performance and performance relationships is by no means exclusive to family firms. All firms have and need to satisfy multiple stakeholders (Freeman, 1984). The stakeholder perspective should be more relevant to nonfamily firms that are aware of and concerned with satisfying multiple stakeholders. A stakeholderbased perspective of performance in nonfamily businesses will differ in terms of stakeholder level of analysis (i.e., there will be no family) and corresponding performance outcomes, but the value of the stakeholder perspective, the performance relationship typology, and our considerations on organizational effectiveness remain constant and can be applied and contextualized to general management and performance literature.

Especially considering the rise of society as an influential stakeholder, as evidenced by environmental (green) movements and the blossoming corporate social responsibility field, implementing a stakeholder perspective in nonfamily firms seems especially timely. In research and practice, identifying overlapping, causal, and, especially, synergistic relationships that are mutuallybeneficial to both business and society will have a lasting impact.

\section{References}

Anderson, R., Mansi, S., \& Reeb, D. (2003). Founding family ownership and the agency cost of debt. Journal of Financial Economics, 68(2), 263-286. 
Anderson, R., \& Reeb, D. (2003). Founding family ownership and firm performance: Evidence from the S\&P 500. Journal of Finance, 58(3), 1308-1328.

Astrachan, J., \& Jaskiewicz, P. (forthcoming). Emotional returns and emotional costs in privately held family businesses: Advancing traditional business valuation. Family Business Review.

Austin, J., Stevenson, H., \& Wei-Skillern, J. (2006). Social and commercial entrepreneurship: Same, different, or both? Entrepreneurship Theory and Practice, 30(1), $1-22$.

Baumol, W. J. (1990). Entrepreneurship: Productive, unproductive, and destructive. Journal of Political Economy, 98(5), 893-921.

Cameron, K., \& Whetten, D. A. (1983). Organizational effectiveness: A comparison of multiple models. New York: Academic Press.

Chakravarthy, B. (1986). Measuring strategic performance. Strategic Management Journal, 7(5), 437-458.

Chrisman, J., \& Carroll, A. (1984). Corporate responsibility-Reconciling economic and social goals. Sloan Management Review, 25(2), 59-65.

Chrisman, J., Chua, J., \& Litz, R. (2004). Comparing the agency costs of family and nonfamily firms: Conceptual issues and exploratory evidence. Entrepreneurship Theory and Practice, 28(4), 335-354.

Chua, J., Chrisman, J., \& Sharma, P. (1999). Defining the family business by behavior. Entrepreneurship Theory and Practice, 23(4), 19-39.

Chua, J., Chrisman, J., \& Steier, L. (2003). Extending the theoretical horizons of family business research. Entrepreneurship Theory and Practice, 27(4), 331338.

Connolly, T., Conlon, E. J., \& Deutsch, S. J. (1980). Organizational effectiveness: A multiple-constituency approach. Academy of Management Review, 5(2), 211-217.

Corbetta, G., \& Salvato, C. (2004). Self-serving or self-actualizing? Models of man and agency costs in different types of family firms: A commentary on "Comparing the agency costs of family and nonfamily firms: Conceptual issues and exploratory evidence". Entrepreneurship Theory and Practice, 28(4), 355-362.

Craig, J., \& Moores, K. (2005). Balanced scorecards to drive the strategic planning of family firms. Family Business Review, 18(2), 105-122.

Davidsson, P., \& Wiklund, J. (2001). Levels of analysis in entrepreneurship research: Current research practice and suggestions for future research. Entrepreneurship Theory and Practice, 25(4), 85-100.

Dess, G. G., Ireland, R. D., Zahra, S. A., Floyd, S. W., \& Janney, J. J. (2003). Emerging issues in corporate entrepreneurship. Journal of Management, 29(3), 351-378.

Doty, D. H., \& Glick, W.H. (1994). Typologies as a unique form of theory building: Toward improved understanding and modeling. Academy of Management Review, 19(2), 230-251.

Douglas, E. J., \& Shepherd, D. A. (2000). Entrepreneurship as a utility maximizing response. Journal of Business Venturing, 15(3), 231-251.

Douglas, E. J., \& Shepherd, D. A. (2002). Self-employment as a career choice: Attitudes, entrepreneurial intentions, and utility maximization. Entrepreneurship Theory and Practice, 26(3), 81-90.

Dunn, B. (1995). Success themes in Scottish family enterprises: Philosophies and practices through the generations. Family Business Review, 8(1), 17-28.

Dyer, G., \& Whetten, D. A. (2006). Family firms and social responsibility: Preliminary evidence from the SP 500. Entrepreneurship Theory and Practice, 30(6), 785-802.

Freeman, C. E. (1984). Strategic management: A stakeholder approach. Boston, MA: Pitman.

Gimeno, J., Folta, T., Cooper, A., \& Woo, C. (1997). Survival of the rittest? Entrepreneurial human capital and the persistence of underperforming firms. Administrative Science Quarterly, 42(4), 750-783.

Gomez-Mejia, L. R., Takacs Haynes, K., Nunez-Nickel, M., Jacobson, K. J. L., \& Moyano-Fuentes, J. (2007). Socioemotional wealth and business risks in familycontrolled firms: Evidence from Spanish olive oil mills. Administrative Science Quarterly, 52(1), 106137.

Habbershon, T. G., Williams, M. L., \& MacMillan, I. C. (2003). A unified system perspective of family firm performance. Journal of Business Venturing, 18, 451465.

Jaskiewicz, P. (2006). Performance-Studie börsennotierter Familienunternehmen in Deutschland, Frankreich und Spanien. Josef Eul Verlag; Reihe FGF Entrepreneurship-Research Monographien; Band 56.

Jensen, M., \& Meckling, W. (1994). The nature of man. Journal of Applied Corporate Finance, 7(2), 4-19.

Kochan, T. A., \& Rubinstein, S. A. (2000). Toward a stakeholder theory of the firm: The Saturn partnership. Organization Science, 11(4), 367-386.

Lansberg, I. (1988) The succession conspiracy. Family Business Review, 1(2), 119-143.

Lee, M., \& Rogoff, E. G. (1996). Comparison of small businesses with family participation versus small businesses without family participation: An investigation of differences in goals, attitudes, and family/business conflict. Family Business Review, 9, 423-437. 
Lewin, A., \& Minton, J. W. (1986). Determining organizational effectiveness: Another look and an agenda for research. Management Science, 32(5), 514-538.

Litz, R. (1997). The family firm's exclusion from business school research: Explaining the void; addressing the opportunity. Entrepreneurship Theory and Practice, 21(3), 55-71.

Lounsbury, M., \& Glynn, M. A. (2001). Cultural entrepreneurship: Stories, legitimacy, and the value of acquisition of resources. Strategic Management Journal, 22(6-7), 545-564.

Lumpkin, G. T., \& Dess, G. (1996). Clarifying the entrepreneurial orientation construct and linking it to performance. Academy of Management Review, 21(1), 135-172.

McGuire, J. B., Sundgren, A., \& Schneeweis, T. (1988). Corporate social responsibility and financial firm performance. Academy of Management Journal, 31(4), 854-872.

McMahon, R. G. P., \& Stanger, A. M. J. (1995). Understanding the small enterprise financial objective function.Entrepreneurship Theory and Practice, 19(4), 21-39.

Melin, L., \& Nordqvist, M. (2007). The reflexive dynamics of institutionalization: The case of the family business. Strategic Organization, 5(4), 321-333.

Miles, R. H. (1980). Macro organizational behavior. Santa Monica, CA: Goodyear.

Mitchell, R. K., Agle, B., \& Wood, D. J. (1997). Toward a theory of stakeholder identification and salience: Defining the principle of who and what really counts. Academy of Management Review, 22(4), 853-886.

Moores, K. J., \& Barrett, M. (2002). Learning family business: Paradox and pathways. London: Ashgate Publishing.

Naughton, T. J. (1987). Quality of working life and the self-employed manager. American Journal of Small Business, 12(2), 33-40.

Olson, P. D., Zuiker, V. S., Danes, S. M., Stafford, K., Heck, R. K. Z., \& Duncan, K. A. (2003). Impact of family and business on family business sustainability. Journal of Business Venturing, 18(5), 639-666.

Penrose, E. T. (1952). Biological analogies in the theory of the firm. American Economic Review, 42(5), 804819.

Poza, E. J., Alfred, T., \& Maheshwari, A. (1997). Stakeholder perceptions of culture and management practices in family and family firms-A preliminary report. Family Business Review, 10(2), 135-155.

Schilling,M.A. (2000). Toward a general modular systems theory and its application to interfirm product modularity. Academy of Management Review, 25(2), 312334.
Schulze, W. S., Lubatkin, M. H., \& Dino, R. M. (2003). Exploring the agency consequences of ownership dispersion among the directors of private family firms. Academy of Management Journal, 46(2), 179-194.

Scott, M., \& Rosa, P. (1996). Has firm level analysis reached its limits? Time for a rethink? International Small Business Journal, 14(4), 81-89.

Sharma, P. (2001). Stakeholder management concepts in family firms. Proceedings of International Association of Business and Society (IABS), 254-259.

Sharma. P. (2003). A typology of family firms using internal stakeholders. Proceedings of the Administrative Sciences Association of Canada's Annual Conference in Halifax. Entrepreneurship Division, 24, 149163.

Sharma, P. (2004). An overview of the field of family business studies: Current status and directions for the future. Family Business Review, 17(1), 1-36.

Sharma, P., \& Manikutty, S. (2005). Strategic divestments in family firms: Role of family structure and community culture. Entrepreneurship Theory and Practice, 29(3), 293-311.

Sirmon, D. G., \& Hitt, M. A. (2003). Managing resources: Linking unique resources, management, and wealth creation in family firms. Entrepreneurship Theory and Practice, 27(2), 339-358.

Sorenson, R. L. (1999). Conflict strategies used by successful family businesses. Family Business Review, 12(4), 325-339.

Sraer, D., \& Thesmar, D. (2006). Performance and behavior of family firms: Evidence from the French stock market (ECGI-Finance Working Paper No. 130/2006). Retrieved July 27, 2008, from http://ssrn.com/ abstract $=925415$

Tagiuri, R., \& Davis, J. (1996). Bivalent attributes of the family firm. Family Business Review, 9(2), 199-208.

Thaler, R. (1985). Mental accounting and consumer choice. Marketing Science, 4(3), 199-214.

Villalonga, B., \& Amit, R. (2006). How do family ownership, control, and management affect firm value? Journal of Financial Economics, 80(2), 385-417.

Vos, E., \& Forlong, C. (1996). The agency advantage of debt over the lifecycle of the firm. Journal of Entrepreneurial \& Small Business Finance, 5(3), 193-212.

Ward, J. (1988). Keeping the family business healthy. San Francisco, CA: Jossey-Bass.

Ward, J. (1997). Growing the family business: special challenges and best practices. Family Business Review, 10(4), 323-337.

Westhead, P., \& Cowling, M. (1997). Performance contrasts between family and nonfamily unquoted companies in the UK. International Journal of Entrepreneurial Behaviour \& Research, 3(1), 30-52. 
Whetten, D. A. (2007). What constitutes a theoretical contribution (in family business scholarship)? Keynote speech at the Family Enterprise Research Conference. Monterrey, Mexico.

Zellweger, T. (2007). Time horizon, costs of equity capital and generic investment strategies of firms. Family Business Review, 20(1), 1-15.

Zellweger, T. Fueglistaller, U., \& Meister R. (2007). The outperformance of family firms: The role of variance in earnings per share and analyst forecast dispersion.
Financial Markets and Portfolio Management, 21(2), 203-220.

Thomas M. Zellweger, University of St. Gallen and Babson College, Dufourstrasse 40a, 9000 St. Gallen; tel: +41 71224 7100; thomas.zellweger@unisg.ch. Robert S. Nason, Babson College, Institute for Family Enterprising, Babson Park (MA); tel: +1781 239 4332; rnason@babson.edu. 